\title{
A review of effective herbal medicines in controlling menopausal symptoms
}

\author{
Rahele Kargozar ${ }^{1}$, Hoda Azizi ${ }^{2}$, Roshanak Salari ${ }^{3}$
}

${ }^{1}$ Ph.D. student of Persian Medicine, Department of Persian Medicine, School of Persian and Complementary Medicine, Mashhad University of Medical Sciences, Mashhad, Iran

${ }^{2}$ M.D., Assistant Professor, Department of Chinese and Complementary Medicine, School of Persian and Complementary Medicine, Mashhad University of Medical Sciences, Mashhad, Iran

${ }^{3}$ Ph.D. of Drug Control, Assistant Professor, Department of Clinical Persian Pharmacy, School of Persian and Complementary Medicine, Mashhad University of Medical Sciences, Mashhad, Iran

Type of article: Review

\begin{abstract}
Background: Acute menopausal syndrome especially hot flashes, is one of the most common gynecological problems during menopause. Due to the side effects of hormone therapy, herbal and complementary medicines are always of immense interest to people in the treatment and management of the symptoms and complications of menopause.

Objective: The aim of this study was to investigate the mechanisms and effects of medicinal plants employed in the treatment of menopausal symptoms.

Methods: This review article was carried out by examining clinical trial studies between the period of 1994 and 2016. The keywords, which include menopause, climacteric, hot flushes, flashes, herb and phytoestrogens were used to search for herbal medicines used in clinical trials for the treatment of menopausal symptoms using databases such as PubMed, Medline, Scopus, Google scholar, SID and Magiran.

Results: The results of the study showed that the medicinal plants, which include Sage herb (Salvia officinalis), Lemon balm (Melissa officinalis), Valerina officinalis, Black cohosh (Cimicifuga racemosa), Fenugreek (Trigonella foenum-graecum), Black cumin (Nigella sativa), Vitex (Vitex agnus-castus), Fennel (Foeniculum vulgare), Evening primrose (Oenothera biennis), Ginkgo biloba, Alfalfa (Medicago sativa), Hypericum perforatum, Panax ginseng, Pimpinella anisum, Licorice (Glycyrrhiza glabra), Passiflora incarnata, Red clover (Trifolium pratense), and Glycine soja were effective in the treatment of acute menopausal syndrome with different mechanisms.

Conclusion: Medicinal plants can play an imperative role in the treatment of acute menopausal syndrome; however, further studies are required to buttress their efficacy in the treatment of acute menopausal syndrome.

Keywords: Menopause, Hot flashes, Phytoestrogens, Medicinal plants, Insomnia, Vaginal atrophy

\section{Introduction}

Biological mechanisms associated with menopause originate from changes that occur in the structure and function of the ovaries. The number of follicles in women before menopause is ten times higher than that in women after menopause. There are almost no follicles in the ovaries of postmenopausal women. This indicates that the number of stored follicles is a determinant factor in menopausal transition period (1). The onset of menopause is associated with a dramatic change in hormonal balance, a decrease in estrogen and increase in FSH and LH hormones, which ultimately reduces the level of progesterone and causes permanent amenorrhea (2). The average age of menopause is 50 years but in people of African origin, it occurs earlier. Nutrition and smoking also affect menopausal age (3). Acute menopausal syndrome includes vasomotor phenomena (hot flashes and night sweats) and psychosomatic
\end{abstract}

\section{Corresponding author:}

Assistant Professor Dr. Roshanak Salari, Department of Clinical Persian Pharmacy, School of Persian and Complementary Medicine, Mashhad University of Medical Sciences, Mashhad, Iran.

Tel: +98.51338829279, Fax: Email: salarir@mums.ac.ir

Received: March 08, 2017, Accepted: June 24, 2017, Published: November 2017

iThenticate screening: June 24, 2017, English editing: September 28, 2017, Quality control: October 25, 2017

(C) 2017 The Authors. This is an open access article under the terms of the Creative Commons Attribution-NonCommercialNoDerivs License, which permits use and distribution in any medium, provided the original work is properly cited, the use is non-commercial and no modifications or adaptations are made. 
symptoms, which are experienced differently in people with different psychological, social, and cultural characteristics (4). Hot flashes are the most common symptom, which are experienced by women during menopause (5). Hot flashes are periodic flushing and sudden sweating disorder with chills, palpitations, anxiety, feeling of pressure in the head and chest, nausea, choking and lack of concentration which usually lasts from between a few seconds to a minute, and rarely lasts up to an hour $(5,6)$. Hot flashes may vary from person to person and is determined by the following factors: alcohol intake, caffeinated products, eating of spicy foods, high ambient temperature, wearing of tight clothing, smoking or exposure to cigarette smoke (5). Urogenital tract atrophy induced by estrogen deficiency can also lead to symptoms such as itching, and dyspareunia, urethritis, dysuria, incontinence and frequency of urination (7). Hormone therapy is one of the most efficacious treatments for reducing vasomotor symptoms and treatment of other complications associated with menopause. However, it has been shown that hormone therapy can induce increased risk of breast cancer and coronary heart disease as well as pulmonary embolism $(5,8)$. Various studies have shown significant propensity of women for complementary therapies and medicinal plants. Several medicinal plants have been studied owing to their effects on vasomotor and psychosomatic symptoms in different studies indicating that phytoestrogens plants are particularly important and effective (6). So far, more than 300 plants with phytoestrogens components have been identified (9). Phytoestrogens are plant components, which are similar to estrogens in structure and function. Phytoestrogens include flavones, lignans, and coumestan $(10,11)$. Several studies have demonstrated that regular consumption of phytoestrogens in the diet of Asian women has led to a reduction in menopausal symptoms (12), breast cancer (13), endometrial cancer (14) and an increase in bone mass (15) compared to other regions. Phytoestrogens induce biological responses in plants, and mimic the functions of endogenous estrogens by binding to estrogen receptors $(10,11)$. The aim of this study is to investigate medicinal plants that have been identified to reduce the symptoms of acute menopausal syndrome.

\section{Material and Methods}

\subsection{Research design and search strategy}

A review study was conducted on Iranian and international articles published between 1994 and 2016 with emphasis on plants used in the treatment and management of the acute symptoms of menopause and their mechanisms of action. The keywords, which include menopause, climacteric, hot flushes, flashes, herb and phytoestrogens were used to search for herbal medicines used in clinical trials for the treatment of menopausal symptoms using databases such as PubMed, Medline, Scopus, Google scholar, SID and Magiran.

\subsection{Inclusion and exclusion criteria}

In this study, abstracts of articles that appeared to be related to the subject of investigation or which the herbal mechanism of action was clearly defined (in clinical or animal studies), were selected. The clinical trials which were selected, follow the CONSORT standard with direct relevance to medicinal plants, the physical and psychological symptoms of menopause. Cell culture studies were excluded from our study.

\subsection{Quality assessment}

Articles following the CONSORT standards were chosen. The risk of bias was assessed by the two reviewers independently.

\section{Results and discussion}

After menopause, the hormonal balance in the body varied when compared with the previous ages. Estradiol and progesterone production reduced leading to a gradual increase in gonadotropins, especially FSH. Adrenal androgens were the major sources of estrogen in the research participants which was secreted in the form of estrone (a weak estrogen) in fatty tissues. Estrogen is a drug of choice that is used in the treatment of hot flashes. Progesterone could be efficacious in women for whom estrogen is contraindicated. Based on the side effects of hormone therapy, medicinal plants have attracted much interest in recent decades. The presence of phytoestrogens and phyto progesterones in medicinal plants and sometimes, the anti-androgen effects of medicinal plants that decrease the conversion of testosterone to dehydrotestosterone and increase the conversion of testosterone and androstenedione to estrogen in peripheral tissues could reduce menopausal symptoms, particularly hot flashes (6). In addition, some herbal drugs that affect the nervous system by activating specific neurotransmitters have been effective in improving sleep and memory symptoms in menopausal women. Medicinal plants with different mechanisms of action are effective in the treatment of menopausal symptoms. The results of the review of literature is shown in Table 1 (1636). Notable among these medicinal plants include the followings (3.1-3.16). 
http://www.ephysician.ir

Table 1. Notable medicinal plants used in controlling menopause syndrome

\begin{tabular}{|c|c|c|c|c|}
\hline References & Type of study & Mechanisms & Effects & $\begin{array}{l}\text { Common name / } \\
\text { Scientific name }\end{array}$ \\
\hline 16,38 & Clinical Trial & $\begin{array}{l}\text { Bind to GABA } \\
\text { complex/benzodiazepine } \\
\text { Receptors in the brain, anti-perspiration } \\
\text { feature, phytoestrogens }\end{array}$ & $\begin{array}{l}\text { Treatment of flashes, sweats } \\
\text { reduction, positive effects on } \\
\text { the nervous system including } \\
\text { improved memory }\end{array}$ & $\begin{array}{l}\text { Sage herb/ Saliva } \\
\text { Officinalis }\end{array}$ \\
\hline 17,39 & $\begin{array}{l}\text { Clinical Trial, } \\
\text { Animal Study }\end{array}$ & $\begin{array}{l}\text { Lemon balm aroma affects the nervous } \\
\text { system }\end{array}$ & $\begin{array}{l}\text { Treatment of sleep disorders, } \\
\text { nervousness, gastrointestinal } \\
\text { problems in menopause }\end{array}$ & $\begin{array}{l}\text { Lemon balm/ Melissa } \\
\text { Officinalis }\end{array}$ \\
\hline $18,19,40$ & $\begin{array}{l}\text { Clinical Trial, } \\
\text { Clinical Trial, } \\
\text { Cell Study }\end{array}$ & Increase of GABA in the synaptic cleft & $\begin{array}{l}\text { Treatment of hot flashes in } \\
\text { menopause }\end{array}$ & $\begin{array}{l}\text { Valerian/ Valerian } \\
\text { Officinalis }\end{array}$ \\
\hline 21 & & $\begin{array}{l}\text { No permanent effect on estrogen } \\
\text { receptors }\end{array}$ & $\begin{array}{l}\text { Treatment of menopause } \\
\text { symptoms such as night } \\
\text { sweat, hot flash, insomnia, } \\
\text { irritability, palpitations and } \\
\text { headache }\end{array}$ & $\begin{array}{l}\text { Cimicifugaracemose/ } \\
\text { Black Cohosh }\end{array}$ \\
\hline 22,23 & $\begin{array}{l}\text { Clinical Trial- } \\
\text { A systematic } \\
\text { review }\end{array}$ & $\begin{array}{l}\text { Inhibit the excess activity of } \\
\text { testosterone }\end{array}$ & $\begin{array}{l}\text { Treatment of vasomotor } \\
\text { symptoms in menopause }\end{array}$ & $\begin{array}{l}\text { Fenugreek/ Trigonella } \\
\text { Foenum }\end{array}$ \\
\hline 24 & Clinical Trial & Visceral body fat reduction & $\begin{array}{l}\text { Treatment of metabolic } \\
\text { syndrome in menopause }\end{array}$ & $\begin{array}{l}\text { The Black Seeds/ } \\
\text { Nigella sativa }\end{array}$ \\
\hline 25,42 & $\begin{array}{l}\text { Clinical Trial, } \\
\text { Randomized } \\
\text { Trial }\end{array}$ & $\begin{array}{l}\text { Stimulate the expression of genes } \\
\text { related to progesterone receptors as } \\
\text { well as its ability to eliminate defects in } \\
\text { the synthesis of progesterone in luteal } \\
\text { phase }\end{array}$ & Treatment of hot flashes & $\begin{array}{l}\text { Hayfork/ Vitex } \\
\text { Agnuscastus }\end{array}$ \\
\hline 26,42 & $\begin{array}{l}\text { Clinical Trial, } \\
\text { Clinical Trial }\end{array}$ & $\begin{array}{l}\text { Retard excessive production of } \\
\text { testosterone }\end{array}$ & $\begin{array}{l}\text { Treatment of menopausal } \\
\text { symptoms and vaginal } \\
\text { atrophy }\end{array}$ & $\begin{array}{l}\text { Fennel/ } \\
\text { FoeniculumVulgare }\end{array}$ \\
\hline 27 & Clinical Trial & $\begin{array}{l}\text { Antioxidant activities, contains } \\
\text { prostaglandin } E_{1}\end{array}$ & $\begin{array}{l}\text { Treatment of vasomotor } \\
\text { symptoms }\end{array}$ & $\begin{array}{l}\text { Oenotherabiennis/ } \\
\text { Evening Prim Rose }\end{array}$ \\
\hline 28 & Clinical Trial & Antioxidant and vasodilator activities & $\begin{array}{l}\text { Treatment of attention } \\
\text { disorders, memory } \\
\text { impairment in } \\
\text { postmenopausal women }\end{array}$ & Ginkgo/ Ginkgo Biloba \\
\hline 29 & Clinical Trial & Estrogenic effects & Treatment of hot flashes & $\begin{array}{l}\text { Alfalfa/ Medicago } \\
\text { Sativa }\end{array}$ \\
\hline 30 & $\begin{array}{l}\text { a randomized } \\
\text { pilot trial, }\end{array}$ & Benzodiazepine receptor activation & Treatment of hot flashes & $\begin{array}{l}\text { Hypericum } \\
\text { (Hvfaryqvn)/ } \\
\text { Hypericume Perforatum } \\
\end{array}$ \\
\hline 31 & $\begin{array}{l}\text { a randomized } \\
\text { pilot trial }\end{array}$ & Estrogenic effects & $\begin{array}{l}\text { Treatment of sleep disorders, } \\
\text { fatigue, menopausal } \\
\text { symptoms }\end{array}$ & Ginseng/ Panax Ginseng \\
\hline 32 & Clinical Trial & Estrogenic effects & Treatment of hot flashes & $\begin{array}{l}\text { Anise/ Pinpinella } \\
\text { Aanisune }\end{array}$ \\
\hline 33 & Clinical Trial & Estrogenic effects & Treatment of hot flashes & $\begin{array}{l}\text { Glycyrrhiza Glabra/ } \\
\text { Licoric }\end{array}$ \\
\hline 34,44 & $\begin{array}{l}\text { Clinical Trial, } \\
\text { Animal Study }\end{array}$ & Activation of GABA $\mathrm{A}_{\mathrm{A}}$ receptor & $\begin{array}{l}\text { Treatment of menopausal } \\
\text { symptoms and hot flashes and } \\
\text { neurological disorders }\end{array}$ & $\begin{array}{l}\text { Passion fruit/ Passiflora } \\
\text { Incarnata }\end{array}$ \\
\hline 35 & Clinical Trial & $\begin{array}{l}\text { Inhibit angiogenesis and provide } \\
\text { protection agonist oxidative damage, } \\
\text { anti-oxidant, estrogenic effect }\end{array}$ & $\begin{array}{l}\text { Ability to reduce menopausal } \\
\text { symptoms and support the } \\
\text { maintenance of bone density } \\
\text { and protect the cardiovascular } \\
\text { and immune system }\end{array}$ & $\begin{array}{l}\text { Red clover/ Trifolium } \\
\text { Pretense }\end{array}$ \\
\hline 36 & Clinical Trial & Estrogenic effects & $\begin{array}{l}\text { Ability to reduce menopausal } \\
\text { symptoms, support the } \\
\text { maintenance of bone density, } \\
\text { protects the immune system }\end{array}$ & Soya/ Glycine soja \\
\hline
\end{tabular}




\subsection{Salvia officinalis}

This herb has a mechanism of action of binding to complex GABA / benzodiazepines receptors in the brain and participates in the treatment of hot flashes and sweats due to its estrogenic effects. In addition, due to its positive impact on the nervous system, it is effective in improving memory and sedation. Its effects in the treatment of excessive sweating have been approved by the Commission E. There are no reports on dangerous side effects induced by therapeutic doses of this plant. The excessive use of this plant causes a feeling of warmth, dizziness, tachycardia and epilepsy-like seizures. It increases the probability of cross-reactivity with diabetes and blood pressure drugs $(37,38)$.

\subsection{Melissa officinalis}

One of its derivatives is caffeic acid. This herb is used to treat nerve stimulation and sleep problems especially in menopause. There is no report on dangerous side effects induced by the intake of therapeutic doses of this herb (37, 39).

\subsection{Valerian officinalis}

Increase in GABA in the synaptic cleft due to inhibition of its reuptake, an increase in the secretion of neurotransmitter, and a considerable amount of glutamine in the plant extract are probably responsible for the sedative effects of the plant roots. In addition, this herb is used in the treatment of hot flashes in menopause. Harmful and dangerous side effects induced by the intake of therapeutic doses of this herb have not been reported $(37,40)$.

\subsection{Black Cohosh}

The herb has been used to treat hot flashes and other menopausal symptoms for many years without permanent effects on estrogen receptors $(20,21)$. Terpene glycosides are the active compounds found in the plant roots. The compounds in the rhizome of the plant bind to the estrogen receptor and selectively suppress the secretion of LH without any effect on FSH. No report on dangerous side effects induced by intake of therapeutic doses of this plant have been reported. Some side effects that result from the consumption of this herb include inflammation of the lining of the stomach and intestines, nausea and vomiting (37).

\subsection{Trigonella foenum:}

This herb contains compounds of mucilage, proteins and steroidal saponins etc. Its lipid lowering effects due to the presence of saponin compounds in the plant, have been proven. Several studies have shown the effects of this plant in the treatment of menopausal symptoms, particularly hot flashes and metabolic syndrome. Harmful and dangerous side effects induced by the intake of therapeutic doses of this plant have not been reported. However, it has been demonstrated that repeated external use of this plant might cause inflammation $(22,23,37)$.

\subsection{Nigella sativa}

It has been shown that this herb is efficacious in the treatment of metabolic syndrome in postmenopausal women; thus, regulating blood sugar and lipids (24).

\subsection{Vitex agnus-castus}

The mechanism of action of the plant is most likely on the hypothalamic-pituitary axis. Although some studies have shown the effect of the plant in increasing the secretion of LH and the amount of progesterone, however, some other studies have reported that this plant has no effect on the LH and FSH (42). On the other hand, its effects on prolactin depends on the amount of the plant used (43). Sometimes, the taking of this herb may lead to nausea, vomiting, dry mouth, headache, dizziness, drowsiness, confusion and anxiety (37).

\subsection{Foeniculum vulgare}

This herb has anti-androgenic, anti-inflammatory effects because of the presence of palmitic acid and beta-sitosterol in the herb (37). Its therapeutic effects have been investigated in hot flashes and vaginal atrophy in post-menopausal women (26). There has been no report on the harmful side effects associated with intake of therapeutic doses of this plant (37).

\subsection{Evening Primrose}

Oenothera biennis oil contains omega-3 fatty acids, which increases prostaglandin E2 that has anti-inflammatory effects (37). Its efficacy in reducing hot flashes associated with menopause has been confirmed by various studies 
(27). Oenothera biennis oil may cause mild gastrointestinal side effects including nausea, vomiting, diarrhea, bloating or lowering of seizure threshold in patients with seizure disorders or those taking antiepileptic drugs (37).

\subsection{Ginkgo biloba}

This plant has anti-inflammatory and antioxidant properties. Its application in the treatment of attention disorders, memory impairment in postmenopausal women has been reiterated by several studies (28). Its side effects include mild gastrointestinal disorders, allergic reactions, headache, muscle spasms, heart palpitations, arrhythmia, dizziness, increased bleeding after surgery, lowering of seizure threshold (37).

\subsection{Medicago sativa (Alfalfa)}

Its effect on hot flashes has been investigated and verified by different studies (29). However, the incidence of hypokalemia and digestive disorders induced by infection with Salmonella, E. coli and Listeria are possible following the consumption of products derived from alfalfa seeds (37).

\subsection{Hypericum perforatum}

Clinical trials showed the effect of the plant extract in the treatment of mild to moderate depression and anxiety and its efficacy on libido, vaginal dryness, urinary tract problems and mental complications caused by menopause (30). The side effects include gastrointestinal discomfort, sensitivity to light, restlessness and fatigue (37).

\subsection{Panax Ginseng}

This plant exhibited anti-inflammatory properties. As a nutritious agent, it can be used orally in the treatment of fatigue, weakness and for improving concentration (37). This plant has been shown to be effective in the treatment of depression and mood disorders in post-menopausal women (31). The side effects include low blood sugar, insomnia, headaches, nervousness, gastrointestinal problems, and acne (37).

\subsection{Pimpinella anisum}

It contains caffeic acid derivatives. The effectiveness of this plant on hot flashes symptoms in menopause has been reported (32). There has been no report on harmful and dangerous side effects that are related to the intake of therapeutic doses of this plant (37).

\subsection{Glycyrrhiza glabra}

It contains terpenes, saponins, flavonoids, isoflavonoids, and steroids (33). It has been shown that this plant is effective in mitigating hot flashes symptoms in menopause (37). However, prolonged use of this herb leads to increase in blood pressure, heart problems, pseudo-hyperaldosteronism, hypercortisolism, hypertension, hypokalemia and hypernatremia (37).

\subsection{Passiflora incarnata}

It contains flavonoids and has phytoprogestrogenic $(16,37)$, anti-anxiety and anti-insomnia effects (37). Its efficacy on neurological symptoms and hot flashes associated with menopause has been reported in some studies (34). So far, no dangerous complications that are related to the consumption of therapeutic doses of this plant have been detected (37).

\subsection{Trifolium pratense}

It contains flavonoids and has phytoestrogenic effects (37). It has been demonstrated that oral intake of supplements containing isoflavones of this plant is efficacious in reducing the frequency and severity of hot flashes (35). However, the concomitant use of this plant with hormonal drugs should be avoided due to cross-reactivity. Some studies suggested that the plant has no effect on hot flashes associated with menopause while others suggested the notable effect of this plant in reducing the frequency and intensity of hot flashes. So far, no dangerous complications that are related to the consumption of therapeutic doses of this plant have been detected (37).

\subsection{Glycine soja}

Soy contains large amounts of protein and isoflavines like daidzein and genistein. The findings of clinical trials suggest that soy extract reduces the frequency of hot flashes in post-menopausal women (37). However, other studies reported that there was no significant difference between the soy and placebo groups. The possible side effects include stomach pain and digestive problems such as diarrhea, prolonged menstrual cycle and contact dermatitis (37). 


\section{Conclusions}

The medicinal herbs examined in this study had effects on the physical and psychological symptoms of menopause at different levels and mechanisms of action. Nevertheless, further studies and clinical trials are required in order to use these medicinal herbs as an original or alternative treatment for acute menopausal syndrome in the near future. The main limitation of this systematic review was the possibility of the presence of publication bias. The quality of the clinical trials was not evaluated by using the Cochrane Collaboration's Risk of Bias Tool, rather the articles were reviewed by one reviewer and cross-checked by another researcher.

\section{Acknowledgments:}

This study was supported by Mashhad University of Medical Sciences Research Council, Mashhad, Iran. The authors have no conflict of interest.

\section{Conflict of Interest:}

There is no conflict of interest to be declared.

\section{Authors' contributions:}

All authors contributed to this project and article equally. All authors read and approved the final manuscript.

\section{References:}

1) Gougeon A. Dynamics of follicular growth in the human: a model from preliminary results. Hum Reprod. 1986; 1: 81-7. PMID: 3558758.

2) Brokaw JJ, Tunnicliff G, Raess BU, Saxon DW. The teaching of complementaryand alternative medicine in U.S. medical schools: a survey of course directors. Acad Med. 2002; 77(9): 876-81. PMID: 12228082.

3) Ginsburg J. What determines the age at the menopause? BMJ. 1991; 302: 1288-9. doi: 10.1136/bmj.302.6788.1288. PMID: 2059681, PMCID: PMC1670030.

4) Prelevic GM, Jacobs HS. Menopause and post-menopause. Baillieres Clin Endocrinol Metab. 1997; 3: 4654. doi: 10.1016/S0950-351X(97)80317-5.

5) Dennerstein L, Smith AMA, Morse C, Burger H, Green A, Hopper J, et al. Menopausal symptoms in Australian women. Med J Aus. 1993; 159: 232-6. PMID: 8412889.

6) Speroff L, Glass K, Kase H. Clinical gynecology and infertility. 7th ed. Philadelphia: Williams \& Wilkings; 2005.

7) Eisenberg DM, Davis RB, Ettner SL. Trends in alternative medicine use in the United States, 1990-1997. JAMA. 1998; 280(18): 1569-75. PMID: 9820257.

8) Ee C, Xue C, Chondros P, Myers SP, French SD, Teede H, et al. Acupuncture for menopausal hot flashes a randomized trial. Ann Intern Med. 2016; 164(3): 146-54. doi: 10.7326/M15-1380. PMID: 26784863.

9) MacLennan A, Lester S, Moore V. Oral estrogen replacement therapy versusplacebo for hot flushes: a systematic review. JAMA. 2001; 4: 58-74. PMID: 11379379.

10) Knight DC, Eden JA. A review of the clinical effects of phytoestrogens. Am J Obstet Gynecol. 1996; 87(5): 897-904. PMID: 8677131.

11) Duncan AM, Phipps WR, Kurzer MS. Phyto-estrogens. Planta Med. 2003; 17(2): 253-71. doi: 10.1055/s0030-1250074. PMCID: PMC3800092.

12) Adlercreutz H, Hamalainen E, Gorbach S, Goldin B. Dietary phyto-estrogens andthe menopause in Japan. Lancet. 1992; 339: 1233. PMID: 1349965.

13) Lee HP, Gourley L, Duffy SW, Esteve J, Lee J, Day NE. Dietary effects on breast cancer risk in Singapore. Lancet. 1991; 337: 1197-1200. doi: 10.1016/0140-6736(91)92867-2. PMID: 1349965.

14) Xu WH, Zheng W, Xiang YB, Ruan ZH, Cheng GR, Dai QI, et al. Soya food intake and risk of endometrial cancer among Chinese women in Shanghai: population based case-control study. BMJ. 2004; 328(7451): 1285. doi: 10.1136/bmj.38093.646215.AE. PMID: 15136343, PMCID: PMC420166.

15) Tsuchida K, Mizushima S, Toba M, Soda K. Dietary soybeans intake and bone mineral density among 995 middle-aged women in Yokohama. Jpn J Clin Oncol. 1999; 9(1): 14-19. PMID: 10098348.

16) Vandecasteele K, Ost P, Oosterlinck W. Evaluation of the efficacy and safety of Salvia officinalis in controlling hot flashes in prostate cancer patients treated with androgen deprivation. Phytotherapy. 2012; 26(2): 208-13. doi: 10.1002/ptr.3528.

17) Taavoni S, Nazem Ekbatani N, Haghani H. Valerian/lemon balm use for sleep disorders during menopause. Complement Ther Clin Pract. 2013; 19(4): 193-6. doi: 10.1016/j.ctcp.2013.07.002. PMID: 24199972. 
18) Kazemian A, Banaian SH, Parvin N, Delaram M. The effect of valerian on hot flash in menopausal women. ijpr. 2006; 8: 35-40.

19) Mirabi P, Mojab F. The effects of valerian root on hot flashes in menopausal women. Iran J Pharm Res. 2013; 12: 217-22. PMID: 24250592, PMCID: PMC3813196.

20) Bradley P. British Herbal Compendium. Bournemouth, Dorset, England: British Herbal Medicine Association; 2000: 35-44.

21) Duker EM, Kopanski L, Jarry H, Wuttke W. Effects of extracts from Cimicifugaracemosaon gonadotropin release in menopausal women. Planta Med. 1991; 57(5): 420-4. doi: 10.1055/s-2006-960139. PMID: 1798794, PMCID: PMC3813196.

22) Hakimi S, Mohammd A, Charadabi S, Siahi M, Bamdad R, Abbasalizadeh F, et al. Effect of Fenugreek seed on early menopausal symptoms. Pharm Sci. 2005; 2: 9.

23) Ghazanfarpour M, Sadeghi R, Abdolahian S, Latifnejad R. The efficacy of Iranian herbal medicines in alleviating hot flashes: A systematic review. Int J Reprod. 2016; 14(3): 155-66.

24) Ibrahim RM, Hamdan NS, Ismail M, Saini SM, Abd Rashid SN, Abd Latiff L, et al. Protective Effects of Nigella sativa on Metabolic Syndrome in Menopausal Women. 2014; 4(1): 29-33. doi: 10.5681/apb.2014.005.

25) Abbaspoor Z, Hajikhani NA, Afshari P. Effect of vitexagnuscactus on menopausal early symptoms in postmenopausal women: A randomized, double-blind, placebo-controlled study. Br J Med Res. 2011; 1: 132-40. doi: 10.9734/BJMMR/2011/163.

26) Yaralizadeh M, Abedi P, Najar S, Namjoyan F, Saki A. Effect of Foeniculumvulgare (fennel) vaginal cream on vaginal atrophy in postmenopausal women: A double-blind randomized placebo-controlled trial. Maturitas. 2016; 84: 75-80. doi: 10.1016/j.maturitas. PMID: 26617271.

27) Chenoy R, Hussain S, Tayob Y, O'Brien PM, Moss MY, Morse PF. Effect of oral gamolenic acid from evening primrose oil on menopausal flushing. BMJ. 1994; 308: 501-3. doi: 10.1136/bmj.308.6927.501. PMID: 8136666, PMCID: PMC2542782.

28) Elsabagh S, Hartley DE, File SE. Limited cognitive benefits in Stage +2 postmenopausal women after 6 weeks of treatment with Ginkgo biloba. J Psychopharmacol. 2005; 19(2): 173-81. doi: 10.1177/0269881105049038. PMID: 15728439.

29) DeLeo V, Lanzetta D, Cazzavacca R, MorganteG. Treatment of neurovegetative menopausal symptoms with a phytotherapeutic agent. Minerva Ginecol. 1998; 50(5): 207-11. PMID: 9677811.

30) AbdaliKh, Khajehei M, Tabatabaee H. Effects of Hypericum perforatum (St. John's wort) on hot flashes and quality of life in perimenopausal women: a randomized pilot trial. Menopause. 2010; 17(2): 326-3.

31) Lindgren R, Mattsson LA, Meier W, Wiklund I. Has Ginsana any estrogen effects when measured by maturity index, plasma FSH, and estradiol? Menopause. 1997; 4: 248. doi: 10.1097/00042192-19970404000046.

32) Nahidi F, Kariman N, Simbar M, Mojab F. The study on the effects of Pimpinellaanisum on relief and recurrence of menopausal hot flashes. Iran J Pharm Res. 2012; 11: 1079. PMID: 24250540, PMCID: PMC3813162.

33) Asgari P, Bahramnezhad F, Narenji F, Golitaleb M, Askari M. A clinical study of the effect of Glycyrrhizaglabra plant and exercise on the quality of life of menopausal women. Prev Chronic Dis. 2015; 3(2): 79-86.

34) Lakhan SE, Vieira KF. Nutritional and herbal supplements for anxiety and anxiety-related disorders: systematic review. Nutr J. 2010; 9: 42. doi: 10.1186/1475-2891-9-42. PMID: 20929532, PMCID: PMC2959081.

35) Ehsanpour S, Salehi K, Zolfaghari B, BakhtiariS. The effects of red clover on quality of life in postmenopausal women. Iran J Nurs Midwif Res. 2012; 17: 34-40. PMID: 23493172, PMCID: PMC3590693.

36) Hanachi P, Golkho S. Assessment of soy phytoestrogens and exercise on lipid profiles and menopause symptoms in menopausal women. J Biol Sci. 2008; 8: 789-93. doi: 10.3923/jbs.

37) Emami A, Fasihi SH, Mehregan I. PDR for Herbal Medicines, 4th ed. Tehran: Institute for the History of Islamic and Complementary Medicine; 1389.

38) Hsieh MT, Wu CR, Wang WH, Lin LW. The ameliorating effect of the water layer of Fructus Schisandrae on cycloheximide-induced amnesia in rats: interaction with drugs acting at neurotransmitter receptors. Pharmacol Res. 2001; 43(1): 17-22. doi: 10.1006/phrs.2000.0756. PMID: 11207061.

39) Orth-Wagner S, Ressin Wj, Friedrich I. Phyto sedativum gegen Schlafstorungen. Z Phytother. 1995; 16(3): 147-56. 
40) Santon MS, Ferreira F, Cunha AP, Carvalho AP, Macedo T. An aqueous extract of Valerian influences the transport of Gaba in synaptosomes. Planta Med. 1994; 60: 278-9. doi: 10.1055/s-2006-959476. PMID: 8073095.

41) Medraś M, Milewicz A, Ziotas G. Evaluation of estradiol response to antiestrogen stimulation in fertile and oligozoospermic men reacting both positively and negatively to chronic treatment with clostilbegyt. Endokrynol Pol. 1993; 44(4): 477-82. PMID: 8055816.

42) Milewicz A, Gejdel E, Sworen H, Sienkiewicz K, Jedrzejak J, Teucher T, et al. Vitex agnus castus extract in the treatment of luteal phase defects due to latent hyperprolactinemia. Results of a randomized placebocontrolled double-blind study. Arzneimittelforschung. 1993; 43(7): 752-6. PMID: 8369008.

43) Javidnia K, Dastgheib L, Mohammadi Samani S, Nasiri A. Antihirsutism activity of Fennel (fruits of Foeniculum vulgare) extract. A double-blind placebo controlled study. Phytomedicine. 2003; 10(6-7): 4558. doi: 10.1078/094471103322331386. PMID: 13678227.

44) Lancel M, Faulhaber J, Holsboer F, Rupprecht R. Progesterone induces changes in sleep comparable to those of agonistic GABAA receptor modulators. Am J Physiol. 1996; 271(4 Pt 1): E763-72. PMID: 8897866 . 